\title{
E que venham os próximos 40 anos: com mais conhecimento e ciência na "Enfermagem em Foco"
}

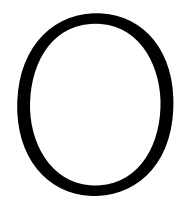

Esta edição da Revista Enfermagem em Foco é especial. Especial, porque sempre que comemoramos a existência das pessoas e instituições, inevitavelmente, a memória nos revela as lembranças do que vivemos e do que construímos.

Neste ano, comemoramos os 40 anos do Conselho Federal de Enfermagem. E sim, com orgulho e muito trabalho, reforçamos aquilo que, em julho de 1973, inspirou a nossa criação: normatizar e fiscalizar o exercício de todos os profissionais de enfermagem, zelando pela qualidade dos serviços prestados à saúde brasileira.

Nessa caminhada, a Revista Enfermagem em Foco registrou em suas páginas a expressão do conhecimento e esforço de centenas de pesquisadores que se dedicam ao aperfeiçoamento da Enfermagem. Artigos científicos, teses e dissertações que revelam a realidade de um país

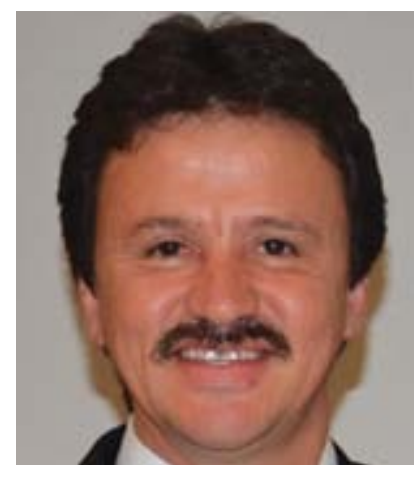
que cresce e se desenvolve a cada dia. Realidade essa, aliás, que nas entrelinhas dos termos técnicos revela a prática de milhares de profissionais que diariamente celebram a vida.

Assim, o que vangloria a comemoração dos 40 anos do Cofen é saber que representamos uma classe nobre e que, por isso, merece condições mais dignas de trabalho. Nesses 40 anos, fechamos um ciclo marcado por avanços políticos, administrativos e, principalmente, por princípios republicanos da democracia e respeito ao bem público. Mas como todo ciclo, esperemos que a renovação seja sempre uma máxima perseguida por aqueles que, de certa forma, fazem parte do Cofen. Almejamos que o profissional de Enfermagem, responsável ativo pela consolidação de uma saúde de excelência, seja o foco de todo o trabalho realizado. Trabalhamos, diariamente, para que as mãos mágicas de todos os profissionais possam transformar a dor em exemplo de vida e coragem. Porque não representamos apenas profissionais, representamos heróis que inspiram a paz e transformam vidas.

Não nos atentaremos a um ufanismo crítico e desmedido. Apenas registraremos nosso dever: os conselhos profissionais preconizam a excelência na prestação do serviço à sociedade. Conselheiros, servidores e todos os colaboradores buscam, incessantemente, pela melhor representatividade da Enfermagem.

Desse modo, saudamos, com muito orgulho, todos os profissionais de

Enfermagem. Almejamos que as páginas da "Revista Enfermagem em Foco" possam transportar a todos os leitores um incentivo para uma formação sólida, séria e atualizada, estimulando, assim, a pesquisa - parte integrante de qualquer projeto que almeje um ensino de qualidade.

A ideia é que possamos nos próximos anos ter mais conquistas em todas as áreas da Enfermagem. A Enfermagem em Foco, no seu pouco tempo de vida, já nos presenteou com grandes conquistas e reconhecimentos internacionais na comunidade científica. Nesta edição, caros leitores, vocês encontrarão um espaço para partilhar vivências, experiências e elaborações teóricas de forma a ampliar cada vez mais esta rede de diálogo e de comunicação da Enfermagem brasileira.

Osvaldo Albuquerque Sousa Filho Presidente interino do Cofen 